\title{
Leucobacter komagatae gen. nov., sp. nov., a New Aerobic Gram-Positive, Nonsporulating Rod with 2,4-Diaminobutyric Acid in the Cell Wall
}

\author{
MARIKO TAKEUCHI, ${ }^{1 *}$ NORBERT WEISS, ${ }^{2}$ PETER SCHUMANN,${ }^{3}$ AND AKIRA YOKOTA ${ }^{1} \dagger$ \\ Institute for Fermentation, Osaka, Yodogawa-ku, Osaka 532, Japan, ${ }^{1}$ and DSM-Deutsche Sammlung von \\ Mikroorganismen und Zellkulturen GmbH, D-07745 Braunschweig, ${ }^{2}$ and DSM-Deutsche \\ Sammlung von Mikroorganismen und Zellkulturen GmbH, Jena, ${ }^{3}$ Germany
}

\begin{abstract}
A new aerobic, gram-positive, nonsporulating rod-shaped organism is described. Strain IFO $15245^{T}(T=$ type strain) has the following characteristics: the menaquinone contains a side chain with 11 isoprenyl units; the guanine-plus-cytosine content of the DNA is $66.2 \mathrm{~mol} \%$; 2,4-diaminobutyric acid, glutamic acid, alanine, glycine, and $\gamma$-aminobutyric acid are present in the cell wall at a molar ratio of ca. 1:1:2:1:1; and glucose and galactose are also present in the cell wall. A comparison of partial 16S rRNA sequences revealed that IFO $15245^{\mathrm{T}}$ represents a distinct line of descent within the gram-positive bacteria with high guanine-plus-cytosine contents. The taxonomic characteristics of this organism are different from those of previously described aerobic, gram-positive, nonsporulating, rod-shaped bacteria. The name Leucobacter komagatae gen. nov., sp. nov., is proposed for this organism. The type strain is strain IFO 15245.
\end{abstract}

The following three genera of gram-positive, aerobic, irregular rods with 2,4-diaminobutyric acid (DAB) in their cell walls have been described previously: the genera Clavibacter (3), Rathayibacter (32), and Agromyces (33). Recently, the new genus Agrococcus (7), whose members also contain DAB in their peptidoglycans, has been proposed. These genera are differentiated by their menaquinone types, the compositions of their cell wall sugars, their DNA $\mathrm{G}+\mathrm{C}$ contents, their pigmentation, and selected physiological features $(1,3,4)$. The menaquinone found in the genus Clavibacter is MK-9, the menaquinone found 10 in the genus Rathayibacter is MK-10, the menaquinone found in the genus Agromyces is MK-12, and the menaquinones found in the genus Agrococcus are MK-11 and MK12.

Strain IFO $15245^{\mathrm{T}}(\mathrm{T}=$ type strain $)$, which was a contaminant in an ampoule labeled "Pseudomonas riboflavina" (18), is a gram-positive, nonmotile, rod-shaped organism. This strain has DAB in its cell wall, and its predominant menaquinone is MK-11. The presence of MK-11 reliably distinguishes strain IFO $15245^{\mathrm{T}}$ from the members of the genera Agrococcus, Agromyces, Clavibacter, and Rathayibacter that have been described, but the taxonomic position of strain IFO $15245^{\mathrm{T}}$ has remained uncertain. To clarify the taxonomic position of this organism and its intergeneric relationships with the previously described gram-positive, high-G+C-content bacteria, we determined a partial 16S rRNA sequence of IFO $15245^{\mathrm{T}}$ and compared it with sequences of 20 representative actinobacteria and related organisms (11).

In this paper, we describe the taxonomic features of strain IFO $15245^{\mathrm{T}}$, and on the basis of morphological, physiological, and chemotaxonomic characteristics and 16S rRNA sequence analysis data we propose that this organism should be classified in the new genus Leucobacter, as Leucobacter komagatae gen. nov., sp. nov.

${ }^{*}$ Corresponding author. Mailing address: Institute for Fermentation, Osaka, 17-85, Juso-honmachi 2-chome, Yodogawa-ku, Osaka 532, Japan. Phone: 06-300-6555. Fax: 06-300-6814.

$\dagger$ Present address: Institute of Molecular and Cellular Biosciences, The University of Tokyo, Yayoi, Bunkyo-ku, Tokyo 113, Japan.

\section{MATERIALS AND METHODS}

Bacterial strains and culture conditions. Strain IFO $15245^{\mathrm{T}}$ was isolated as a contaminant in an ampoule labeled "P. riboflavina" IFO 13584, which was recently reidentified as Devosia riboflavina (18), and maintained in the Institute for Fermentation, Osaka. Strain IFO $15245^{\mathrm{T}}$ was cultivated aerobically at $28^{\circ} \mathrm{C}$ in a peptone-yeast extract medium supplemented with brain heart infusion (Difco Laboratories, Detroit, Mich.), which contained $1 \%$ peptone, $0.2 \%$ yeast extract, $0.2 \%$ brain heart infusion, $0.2 \% \mathrm{NaCl}$, and $0.2 \%$ D-glucose (pH 7.0) (PY-BHI medium). Cells used for biochemical tests were harvested by centrifugation during the stationary phase, washed with water, and lyophilized.

Morphological, physiological, and biochemical characteristics. Cell morphology was determined by phase-contrast microscopy following cell growth on PYBHI agar. Motility was determined by the hanging drop method. Unless otherwise indicated, all tests were performed at $28^{\circ} \mathrm{C}$. Catalase activity was determined by the presence of bubbles in a $3 \%$ hydrogen peroxide solution. Oxidase activity was determined by the oxidation of $1 \%$ tetramethyl-p-phenylenediamine on filter paper. Acid production from carbohydrates was studied in a medium containing $0.3 \%$ peptone, $0.25 \% \mathrm{NaCl}, 0.003 \%$ bromcresol purple, and $0.5 \%$ carbohydrate (pH 7.2) (27). Organic acid assimilation was studied in a medium containing $0.5 \%$ organic acid (sodium salt), $0.02 \%$ D-glucose, $0.01 \%$ yeast extract, $0.01 \%$ Trypticase (BBL), $0.1 \% \mathrm{~K}_{2} \mathrm{HPO}_{4}, 0.5 \% \mathrm{NaCl}, 2 \%$ agar, and $12 \mathrm{mg}$ of phenol red per liter ( $\mathrm{pH} 7.0)$ (27). Nitrate reduction and hydrolysis of starch, gelatin, casein, esculin, Tween 20 , Tween 40 , Tween 60 , and Tween 80 were determined by the methods described by Cowan and Steel (2).

Chemical analyses. Cell walls were prepared from ca. $500 \mathrm{mg}$ (dry weight) of bacterial cells as described by Schleifer and Kandler (21). Amino acids in an acid hydrolysate of the cell walls were identified by two-dimensional descending chromatography on cellulose thin-layer chromatography plates (Tokyo Kasei Co., Ltd., Tokyo, Japan) by the method of Harper and Davis (8) and by highperformance liquid chromatography (HPLC) as their phenylthiocarbamoyl derivatives with a model LC-6AD HPLC apparatus (Shimadzu Co., Ltd., Kyoto, Japan) equipped with a Wakopak WS-PTC column (Wako Pure Chemical Industries, Ltd., Osaka, Japan) according to the manufacturer's instructions (27). The molar ratio of amino acids was determined with an amino acid analyzer (Hitachi Co., Ltd., Tokyo, Japan). An unknown amino acid was identified by electrospray ionization mass spectrometry. The optical configurations of the amino acids were determined as described by Kandler and König (12). Cell wall sugars were analyzed as described by Mikami and Ishida (15). Polar lipids and fatty acids were extracted from dried cells, purified $(17,22)$, and examined as described previously $(29,30)$. Mycolic acids were analyzed by the method of Minnikin et al. (16). The glycolyl test was performed by the method of Uchida and Aida (26).

DNA base composition. DNA was obtained by the method of Saito and Miura (19). The $\mathrm{G}+\mathrm{C}$ content of the DNA was determined by a modification of the method of Mesbah et al. $(14,29,30)$.

$16 S$ ribosomal DNA sequence determination and phylogenetic analysis. Wet cells $(1$ to $3 \mathrm{mg}$ ) were suspended in $300 \mu \mathrm{l}$ of InstaGene purification matrix (Bio-Rad Co., Ltd.), and the resulting preparation was incubated at $56^{\circ} \mathrm{C}$ for 15 to $30 \mathrm{~min}$, sonicated at $100 \mathrm{~W}$ for $30 \mathrm{~s}$, and heated at $100^{\circ} \mathrm{C}$ for $5 \mathrm{~min}$. After centrifugation at $1,000 \times g$ for 2 to $3 \mathrm{~min}$, the supernatant was subjected to PCR amplification (9). Amplification was carried out with a Taq polymerase kit (Ce- 
TABLE 1. Phenotypic and chemotaxonomic characteristics of strain IFO $15245^{\mathrm{T}}$

\begin{tabular}{|c|c|}
\hline Characteristic & Strain IFO $15245^{\mathrm{T}}$ \\
\hline \multicolumn{2}{|l|}{ Phenotypic characteristics } \\
\hline \multicolumn{2}{|c|}{ Catalase activity } \\
\hline \multicolumn{2}{|c|}{ Oxidase activity ..................................................- } \\
\hline \multicolumn{2}{|c|}{ Hydrolysis of: } \\
\hline \multicolumn{2}{|c|}{ 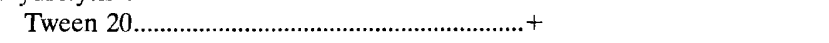 } \\
\hline \multicolumn{2}{|c|}{ Tween $40 \ldots \ldots \ldots \ldots \ldots \ldots \ldots$} \\
\hline \multicolumn{2}{|c|}{ Tween 60} \\
\hline \multicolumn{2}{|c|}{ Tween 80} \\
\hline \multicolumn{2}{|c|}{ Gelatin...........................................................- } \\
\hline \multicolumn{2}{|c|}{ 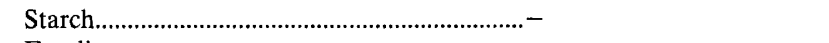 } \\
\hline \multicolumn{2}{|c|}{ Esculin } \\
\hline \multicolumn{2}{|c|}{ Urease formation } \\
\hline \multicolumn{2}{|c|}{$\mathrm{H}_{2} \mathrm{~S}$ formation } \\
\hline \multicolumn{2}{|c|}{ Indole formation...............................................- } \\
\hline \multicolumn{2}{|c|}{ Nitrate reduction ..................................................- } \\
\hline \multicolumn{2}{|c|}{ Voges-Proskauer reaction................................... - } \\
\hline \multicolumn{2}{|c|}{ Methyl red test ................................................ } \\
\hline \multicolumn{2}{|c|}{ Arginine dihydrolase activity .............................. } \\
\hline \multicolumn{2}{|c|}{ Growth in the presence of $2.0 \% \mathrm{NaCl}$..........+ } \\
\hline \multicolumn{2}{|c|}{ Growth in the presence of $5.0 \% \mathrm{NaCl} \ldots \ldots \ldots . .+$} \\
\hline \multicolumn{2}{|c|}{ Growth at $\mathrm{pH} 5$} \\
\hline \multicolumn{2}{|c|}{ Growth at pH $10 \ldots \ldots \ldots \ldots \ldots \ldots \ldots \ldots \ldots \ldots \ldots \ldots \ldots \ldots \ldots$} \\
\hline \multicolumn{2}{|c|}{ Assimilation of: } \\
\hline \multicolumn{2}{|c|}{ 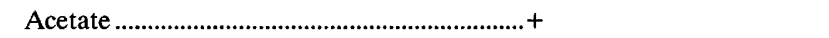 } \\
\hline \multicolumn{2}{|c|}{ 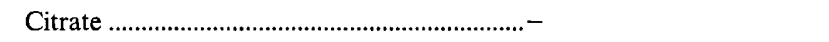 } \\
\hline \multicolumn{2}{|c|}{ Formate ........................................................- } \\
\hline \multicolumn{2}{|c|}{ D- and L-Lactate } \\
\hline Malate ........................................ & \\
\hline Succinate ................................ & \\
\hline Formate...$\ldots \ldots \ldots \ldots \ldots \ldots \ldots \ldots \ldots \ldots$ & \\
\hline 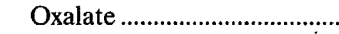 & \\
\hline Hippurate & \\
\hline Chemotaxonomic characterist & \\
\hline $\begin{array}{l}\text { Alanine-glutamic acid-DAI } \\
\text { aminobutyric acid ratio in }\end{array}$ & $1.00: 0.85: 0.89: 0.72$ \\
\hline Galactose-glucose ratio in c & $: 0.60$ \\
\hline Cell wall acyl type................. & \\
\hline Mycolic acid............................... & \\
\hline Quinone system...................... & \\
\hline 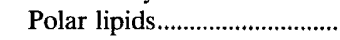 & $\mathrm{G}, \mathrm{PG}, \mathrm{GL}^{a}$ \\
\hline Cellular fatty acids.................. & $\begin{array}{l}\text { iso- } \mathrm{C}_{15: 0}, \text { anteiso- } \mathrm{C}_{17: 0}, \\
\mathrm{o}-\mathrm{C}_{16: 0}\end{array}$ \\
\hline $\mathrm{G}+\mathrm{C}$ content $(\mathrm{mol} \%)$ & \\
\hline
\end{tabular}

${ }^{a}$ Abbreviations: DPG, diphosphatidylglycerol; PG, phosphatidylglycerol; GL, glycolipid.

tus, Inc.), and the purified PCR products were sequenced by using a Sequenase kit for ${ }^{35}$ S-dATP (United Biochemical Inc.) and 12 primers as previously described (24). DNA sequences were aligned by using the ODEN system (10). Nucleotide substitution rates ( $K_{\text {nuc }}$ values) were calculated (13), and a phyloge- netic tree was constructed by the neighbor-joining method (20). The topology of the phylogenetic tree was evaluated by the bootstrap resampling method of Felsenstein (5) with 1,000 replicates.

Nucleotide sequence accession numbers. The sequences which we determined were aligned with previously published sequences that have been deposited in the DDBJ, GenBank, and EMBL data libraries under the following accession numbers: Agrococcus jenensis, X92492; Agromyces cerinus subsp. cerinus, D45060; Agromyces fucosus subsp. hippuratus, D45061; Agromyces mediolanum, X77449; Agromyces ramosus, X77434; Arthrobacter globiformis, M23411; Aureobacterium liquefaciens, X77437; Aureobacterium testaceum, X77438; Brevibacterium linens, X77440; Clavibacter michiganense subsp. insidiosus, D45051; Clavibacter michiganense subsp. michiganense, X77441; “Corynebacterium aquaticum," X77443; Curtobacterium citreum, X77445; Kineococcus aurantiacus (25, 31), D17527; Microbacterium arborescens, D21339; Microbacterium lacticum, D21343; Micrococcus luteus, M38242; Rathayibacter rathayi, X77450; Rathayibacter tritici, X77438; and Renibacterium salmoninarum, X51601. The nucleotide sequence of IFO $15245^{\mathrm{T}}$ has been deposited in the DDBJ database under accession number D17751.

\section{RESULTS}

Phenotypic and chemotaxonomic characteristics. Strain IFO $15245^{\mathrm{T}}$ was a gram-positive, nonmotile, rod-shaped organism. The cells were 0.2 to $0.3 \mu \mathrm{m}$ wide and 1.0 to $1.5 \mu \mathrm{m}$ long. On PY-BHI agar, this strain formed rough, round, convex, pale brown colonies. The biochemical and chemotaxonomic characteristics of strain IFO $15245^{\mathrm{T}}$ are summarized in Table 1 . The amino acids found in the cell wall hydrolysate were alanine, glutamic acid, DAB, glycine, and an unknown amino acid; the molar ratio of these compounds was 1.90:1.00: 0.85:0.89:0.72. The unknown amino acid was analyzed by thinlayer chromatography, by HPLC, with an amino acid analyzer, and by electrospray ionization mass spectrometry and was identified as $\gamma$-aminobutyric acid. The optical rotations of alanine, glutamic acid, and DAB were $\mathrm{D}$ - and L-alanine, D-glutamic acid, and L-DAB. D-DAB was not detected. However, a more detailed structure of the peptidoglycan was not deduced.

Only a small amount of glycolate was found in the acid hydrolysate of bacterial cells, which suggested that muramic acid occurred in the $N$-acetyl form. The major sugars were galactose and glucose. The isoprenoid quinones were menaquinones MK-11 (72\%), MK-10 (16\%), and MK-12 (12\%) (Table 2). The major fatty acids were anteiso- $\mathrm{C}_{15: 0}(65 \%)$, iso- $\mathrm{C}_{16: 0}(13 \%)$, and anteiso- $\mathrm{C}_{17: 0}(22 \%)$. Diphosphatidylglycerol, phosphatidylglycerol, and one unknown glycolipid were identified by thin-layer chromatography and their staining characteristics. The $\mathrm{G}+\mathrm{C}$ content of the DNA was $66.2 \mathrm{~mol} \%$.

Phylogenetic analysis. A total of 1,524 nucleotides of the $16 \mathrm{~S}$ ribosomal DNA of IFO $15245^{\mathrm{T}}$ were sequenced, and the primary structure was aligned with the primary structures of 20 reference actinobacteria. Because only partial sequences were available for some of the reference strains, sequence similarity calculations were based on 1,196 nucleotides. The phylogenetic

TABLE 2. Menaquinone compositions of strains

\begin{tabular}{|c|c|c|c|c|c|c|c|c|}
\hline \multirow{2}{*}{ Strain } & \multicolumn{8}{|c|}{ Menaquinone composition (\%) } \\
\hline & MK-7 & MK-8 & MK-9 & MK-10 & MK-11 & MK-12 & MK-13 & MK-14 \\
\hline IFO $15245^{\mathrm{T}}$ & & & & 16 & 72 & 12 & & \\
\hline Agrococcus jenensis DSM $9580^{\mathrm{T} a}$ & & & & 7 & 37 & 49 & 5 & \\
\hline Agrococcus jenensis DSM 9996 & & & & 4 & 41 & 41 & 13 & \\
\hline Agromyces mediolanum IFO $15704^{\mathrm{T}}$ & & & & 8 & 20 & 67 & 5 & \\
\hline Agromyces cerinus subsp. cerinus JCM $9083^{\mathrm{T} b}$ & & & 1 & 7 & 8 & 60 & 21 & 1 \\
\hline Agromyces fucosus subsp. hippuratus JCM $9086^{\mathrm{T} b}$ & & & 1 & 7 & 9 & 57 & 24 & 2 \\
\hline Agromyces ramosus JCM $3168^{b}$ & & & & 7 & 7 & 56 & 14 & \\
\hline Clavibacter michiganense subsp. michigenense JCM $3345^{b}$ & 9 & 15 & 65 & 11 & & & & \\
\hline Rathayibacter rathayi JCM $9307^{\mathrm{T} b}$ & & & 15 & 74 & 6 & & & \\
\hline
\end{tabular}

\footnotetext{
${ }^{a}$ Data from reference 7 .

${ }^{b}$ Data from reference 23
} 


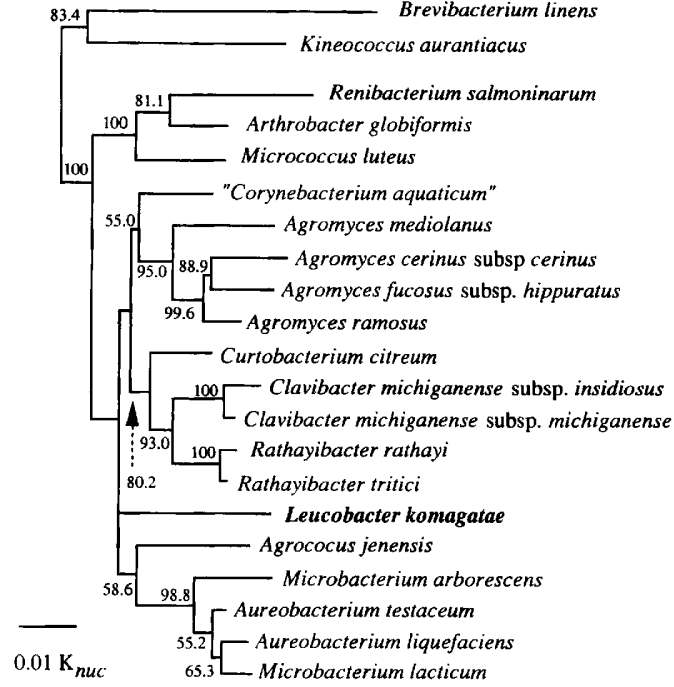

FIG. 1. Unrooted phylogenetic tree showing the relationship of strain IFO $15245^{\mathrm{T}}$ to reference organisms. The numbers indicate the percentages of bootstrap samples, derived from 1,000 samples, that supported the internal branches (5). Bar $=0.01 K_{\text {nuc }}$ unit. dendrogram in Fig. 1 shows that IFO $15245^{\mathrm{T}}$ belongs to the radiation of actinobacteria that contain group $B$ peptidoglycans and represents a distinct lineage. The levels of sequence similarity between strain IFO $15245^{\mathbf{T}}$ and Agrococcus jenensis, Agromyces species, Clavibacter species, and Rathayibacter species were $95.2,93.7$ to $94.6,94.4$ to 94.8 , and 94.6 to $94.9 \%$, respectively. Thus, strain IFO $15245^{\mathrm{T}}$ is equidistant from all linages of DAB-containing strains.

\section{DISCUSSION}

Characteristics that differentiate strain IFO $15245^{\mathrm{T}}$ from four other genera with DAB in their peptidoglycans are shown in Table 3. Strain IFO $15245^{\mathrm{T}}$ hydrolyzes Tween 20 , Tween 40 , Tween 60 , and Tween 80 , but species belonging to the genera Clavibacter, Rathayibacter, Agromyces, and Agrococcus do not. In contrast to Agrococcus species, starch and esculin are not hydrolyzed by strain IFO $15245^{\mathrm{T}}$. The major menaquinones of the genera Clavibacter, Rathayibacter, and Agromyces are MK9, MK-10, and MK-12, respectively, while the major menaquinone of IFO $15245^{\mathrm{T}}$ is MK-11. Agrococcus jenensis contains nearly equimolar concentrations of $\mathrm{MK}-11$ and $\mathrm{MK}-12$. In Agrococcus jenensis, the whole-cell sugars include rhamnose. Rhamnose, xylose, fucose, and/or tyvelose are present in the cell walls of Clavibacter, Rathayibacter, and Agromyces species,

TABLE 3. Some diagnostic and differentiating characteristics of strain IFO $15245^{\mathrm{T}}$ and the genera Clavibacter, Rathayibacter, Agromyces, and Agrococcus

\begin{tabular}{|c|c|c|c|c|c|}
\hline Characteristic & IFO $15245^{\mathrm{T}}$ & Clavibacter $^{a}$ & Rathayibacter $^{b}$ & Agromyces $^{c}$ & Agrococcus $^{d}$ \\
\hline \multicolumn{6}{|l|}{ Utilization of: } \\
\hline Acetate & $+^{e}$ & - & + & ND & - \\
\hline Formate & - & - & + & ND & - \\
\hline Hippurate & + & ND & - & $\mathrm{v}$ & - \\
\hline \multicolumn{6}{|l|}{ Hydrolysis of: } \\
\hline Tween 20 & + & - & - & - & ND \\
\hline Tween 40 & + & ND & - & $\mathrm{v}$ & ND \\
\hline Tween 60 & + & ND & - & - & ND \\
\hline Tween 80 & + & - & - & - & - \\
\hline Starch & - & - & - & $\mathrm{v}$ & + \\
\hline Esculin & - & $\mathrm{v}$ & - & + & + \\
\hline Urea & + & - & - & - & - \\
\hline Nitrate reduction & - & - & - & $\mathrm{v}$ & - \\
\hline $\mathrm{H}_{2} \mathrm{~S}$ formation & + & - & ND & ND & + \\
\hline \multicolumn{6}{|l|}{ Growth in the presence of: } \\
\hline $2.0 \% \mathrm{NaCl}$ & + & + & + & + & + \\
\hline $4.0 \% \mathrm{NaCl}$ & + & ND & + & - & + \\
\hline $5.0 \% \mathrm{NaCl}$ & + & - & $\mathrm{v}$ & - & + \\
\hline Usual source(s) of isolation & Air & Plants, plant substrates & Plants & Soil & Soil, sandstone surfaces \\
\hline Murein type & B & $\mathrm{B} 2 \gamma^{f}$ & $\mathrm{~B} 2 \gamma$ & $\mathrm{B} 2 \gamma$ & B \\
\hline Cell wall diamino acid & L-DAB & D- and $\mathrm{L}-\mathrm{DAB} \mathrm{B}^{g}$ & $\mathrm{D}-$ and L-DAB ${ }^{h}$ & $\mathrm{D}-$ and $\mathrm{L}-\mathrm{DAB}{ }^{h}$ & DAB \\
\hline \multicolumn{6}{|l|}{ Cell wall sugars } \\
\hline Glucose & + & + & + & $\mathrm{v}$ & + \\
\hline Galactose & + & + & $\mathrm{v}$ & + & - \\
\hline Mannose & - & + & + & $\mathrm{v}$ & - \\
\hline Rhamnose & - & + & + & + & + \\
\hline Xylose & - & - & $\mathrm{v}$ & $\mathrm{v}$ & - \\
\hline Fucose & - & $\mathrm{v}$ & - & $\mathrm{v}$ & - \\
\hline Tyvelose & - & - & - & $\mathrm{v}$ & - \\
\hline Major menaquinone(s) & MK-11 & MK-9 & MK-10 & MK-12 & MK-11, MK-12 \\
\hline $\mathrm{G}+\mathrm{C}$ content $(\mathrm{mol} \%)$ & 66 & $65-75$ & $63-72$ & $70-72$ & 74 \\
\hline
\end{tabular}

a Data from reference 3

${ }^{b}$ Data from reference 32 .

${ }^{c}$ Data from references 23 and 33.

${ }^{d}$ Data from reference 7.

$e+$, positive reaction; - , negative reaction; $v$, reaction variable among strains; ND, not determined.

${ }^{f}$ Data from reference 21 .

${ }^{g}$ Data from reference 6.

${ }^{h}$ Data from references 6 and 21 . 
but these sugars are not present in the cell walls of strain IFO $15245^{\mathrm{T}}$. The peptidoglycan type of strain IFO $15245^{\mathrm{T}}$ also differentiates this organism from members of other DAB-containing genera. The peptidoglycan type of the genera Agromyces, Clavibacter, and Rathayibacter is type B2 $\gamma$, which includes $D-D A B$ as well as L-DAB. It has been suggested that $D-D A B$ is present in the interpeptide bridge $(1,6,32,33)$. In strain IFO $15245^{\mathrm{T}}, \mathrm{D}-\mathrm{DAB}$ was not detected in the peptidoglycan.

The low levels of similarity of the 16S rRNA gene sequence indicated that strain IFO $15245^{\mathrm{T}}$ represents a distinct linage within the coryneform bacteria. Thus, strain IFO $15245^{\mathrm{T}}$ can be readily distinguished from all previously described taxa and warrants a new taxon.

On the basis of the distinct peptidoglycan features, $16 \mathrm{~S}$ ribosomal DNA sequence, and nutritional properties of strain IFO $15245^{\mathrm{T}}$, we propose that this strain should be placed in a new genus, the genus Leucobacter, as a member of the type species, Leucobacter komagatae. Moreover, this is the first report of the unusual amino acid $\boldsymbol{\gamma}$-aminobutyric acid, which is present in the peptidoglycan of L. komagatae IFO $15245^{\mathrm{T}}$, as a major component of the cell wall of a bacterium.

Descriptions of the new genus and new species are given below.

Description of Leucobacter gen. nov. Leucobacter (Leu.co. bac'ter. Gr. adj. leucus, clear, light; Gr. masc. m. bacter, rod; M.L. masc. n. Leucobacter, colorless rod) cells are gram-positive, nonsporulating, nonmotile rods. No mycelium is produced. Catalase is produced, but oxidase, arginine dihydrolase, hydrogen sulfide, and urease are not produced.

The $\mathrm{G}+\mathrm{C}$ content of the DNA is $66 \mathrm{~mol} \%$. The cell wall peptidoglycan contains $\mathrm{L}-\mathrm{DAB}$ as a diamino acid. The glycan moiety of the peptidoglycan contains acetyl residues. The major isoprenoid quinone is menaquinone MK-11. Mycolic acid is not present. The major cellular fatty acids are anteiso- $\mathrm{C}_{15: 0}$, iso- $\mathrm{C}_{16: 0}$, and anteiso- $\mathrm{C}_{17: 0}$. Diphosphatidylglycerol, phosphatidylglycerol, and one unknown glycolipid are present.

The type species is Leucobacter komagatae.

Description of Leucobacter komagatae sp. nov. Leucobacter komagatae (koma.ga'tae. N.L. adj. komagatae, of Komagata, in honor of Kazuo Komagata, the Japanese microbiologist who first recognized this strain). Cells are gram-positive, irregular rods that are 0.2 to $0.3 \mu \mathrm{m}$ wide and 1.0 to $1.5 \mu \mathrm{m}$ long. The cells are nonsporulating and nonmotile in 2-day-old cultures on PY-BHI agar. No mycelium is produced. Colonies are circular, entire, low convex, smooth, opaque, and whitish brown. Catalase is produced, but oxidase, arginine dihydrolase, hydrogen sulfide, and urease are not produced. Gelatin, starch, and esculin are not hydrolyzed, but Tween 20 , Tween 40 , Tween 60 , and Tween 80 are hydrolyzed. Nitrate is not reduced. Growth occurs in the presence of 2.0 to $5.0 \% \mathrm{NaCl}$ and at $\mathrm{pH} 10.0$. Acetate, D- and L-lactate, malate, succinate, propionate, oxalate, and hippurate are assimilated, but citrate and formate are not assimilated. The $\mathrm{G}+\mathrm{C}$ content of the DNA is $66 \mathrm{~mol} \%$. The cell wall peptidoglycan contains L-DAB, alanine, glycine, $\gamma$-aminobutyric acid, and glutamic acid. The acyl type of the cell wall is an acetyl type. The major isoprenoid quinone is menaquinone MK-11. Mycolic acids are not present. The major cellular fatty acids are anteiso- $\mathrm{C}_{15: 0}$, iso- $\mathrm{C}_{16: 0}$, and anteiso$C_{17: 0}$. No diagnostic sugar is present in the cell wall. Diphosphatidylglycerol, phosphatidylglycerol, and one unknown glycolipid are present. Isolated as a contaminant on an agar plate.

The type strain is strain IFO 15245 (= IAM 1093).

\section{ACKNOWLEDGMENTS}

We are grateful to Kazuo Komagata, Tokyo University of Agriculture, for providing the bacterial strain and for valuable suggestions and discussions and to Kinya Uchida, University of Tokyo, for help in determining the acyl type of the peptidoglycan.

This research was supported in part by Grant-in-Aid for Co-operative Research 03304017 from the Ministry of Education, Science and Culture, Japan.

\section{REFERENCES}

1. Bendinger, B., R. M. Kroppenstedt, S. Klatte, and K. Altendorf. 1992. Chemotaxonomic differentiation of coryneform bacteria isolated from biofilters. Int. J. Syst. Bacteriol. 42:472-486.

2. Cowan, S. T., and K. J. Steel. 1965. Manual for the identification of medical bacteria. Cambridge University Press, London.

3. Davis, M. J., A. G. Gillaspie, Jr., A. K. Vidaver, and R. W. Harris. 1984 Clavibacter: a new genus containing some phytopathogenic coryneform bacteria, including Clavibacter xyli subsp. xyli sp. nov., pathogens that cause ratoon stunting disease of sugarcane and bermudagrass stunting disease. Int. J. Syst. Bacteriol. 34:107-117.

4. Döpfer, H., E. Stackebrandt, and F. Fiedler. 1982. Nucleic acid hybridization studies on Microbacterium, Curtobacterium, Agromyces and related taxa. J. Gen. Microbiol. 126:1697-1708.

5. Felsenstein, J. 1985. Confidence limits on phylogenies: an approach using the bootstrap. Evolution 39:783-791.

6. Fiedler, E., and O. Kandler. 1973. Die Aminosäuresequenz von 2,4-Diaminobuttersäure enthaltenden Mureiner bei verschiedenen coryneformen Bakterien und Agromyces ramosus. Arch. Mikrobiol. 89:51-66.

7. Groth, I., P. Schumann, N. Weiss, K. Martin, and F. A. Rainey, 1996. Agrococcus jenensis gen. nov., sp. nov., a new genus of actinomycetes with diaminobutyric acid in the cell wall. Int. J. Syst. Bacteriol. 46:234-239.

8. Harper, J. J., and G. H. G. Davis. 1979. Two-dimensional thin-layer chromatography for amino acid analysis of bacterial cell walls. Int. J. Syst. Bacteriol. 29:56-58.

9. Hiraishi, A. 1992. Direct automated sequencing of 16S rRNA amplified by polymerase chain reaction from bacterial culture without DNA purification. Lett. Appl. Microbiol. 15:210-213.

10. Ina, Y. 1991. Molecular evolutionary analysis system for DNA and amino acid sequences (ODEN), version 1.1. DNA Data Bank of Japan, DNA Research Center, National Institute of Genetics, Mishima, Japan.

11. Jones, D., and M. D. Collins. 1986. Section 15. Irregular, nonsporing Grampositive rods, p. 1261-1434. In P. H. A. Sneath, N. S. Mair, M. E. Sharpe, and J. G. Holt (ed.), Bergey's manual of systematic bacteriology, vol. 2. The Williams \& Wilkins Co., Baltimore.

12. Kandler, O., and H. König. 1978. Chemical composition of the peptidoglycan-free cell walls of methanogenic bacteria. Arch. Microbiol. 118:141-152.

13. Kimura, M. 1980 . A simple method for estimating evolutionary rates of base substitutions through comparative studies of nucleotide sequences. J. Mol. Evol. 16:111-120.

14. Mesbah, M., U. Premachandran, and W. E. Whitman. 1989. Precise measurement of the $\mathrm{G}+\mathrm{C}$ content of deoxyribonucleic acid by high-performance liquid chromatography. Int. J. Syst. Bacteriol. 39:159-167.

15. Mikami, H., and Y. Ishida. 1983. Post-column fluorometric detection of reducing sugars in high-performance liquid chromatography using arginine. Bunseki Kagaku 32:E207-E210.

16. Minnikin, D. E., L. Alshamaony, and M. Goodfellow. 1975. Differentiation of Mycobacterium, Nocardia and related taxa by thin-layer chromatographic analysis of whole-organism methanolysates. J. Gen. Microbiol, 88:200-206.

17. Minnikin, D. E., M. D. Collins, and M. Goodfellow. 1979. Fatty acid and polar lipid composition in the classification of Cellulomonas, Oerskovia and related taxa. J. Appl. Bacteriol. 47:87-95.

18. Nakagawa, Y., T. Sakane, and A. Yokota. 1996. Transfer of "Pseudomonas riboflavina" (Foster 1944), a gram-negative, motile rod with long-chain 3-hydroxy fatty acids, to Devosia riboflavina gen. nov., sp. nov., nom. rev. Int. J. Syst. Bacteriol. 46:16-22.

19. Saito, H., and K. Miura. 1963. Preparation of transforming deoxyribonucleic acid by phenol treatment. Biochim. Biophys. Acta 72:619-629.

20. Saitou, N., and M. Nei. 1987. The neighbor-joining method: a new method for reconstructing phylogenetic trees. Mol. Biol. Evol. 4:406-425.

21. Schleifer, K. H., and O. Kandler. 1972. Peptidoglycan types of bacterial cell walls and their taxonomic implications. Bacteriol. Rev. 36:407-477.

22. Suzuki, K., and K. Komagata. 1983. Taxonomic significance of cellular fatty acid composition in some coryneform bacteria. Int. J. Syst. Bacteriol. 33: $188-200$.

23. Suzuki, K., J. Sasaki, M. Uramoto, T. Nakase, and K. Komagata. 1996. Agromyces mediolanus sp. nov., nom. rev., comb. nov., a species for "Corynebacterium mediolanum" Mamoli 1939 and for some aniline-assimilating bacteria which contain 2,4-diaminobutyric acid in the cell wall peptidoglycan. Int. J. Syst. Bacteriol. 46:88-93.

24. Takeuchi, M., F. Kawai, Y. Shimada, and A. Yokota. 1993. Taxonomic study 
of polyethylene glycol-utilizing bacteria: emended description of the genus Sphingomonas and new description of Sphingomonas macrogoltabidus $\mathrm{sp}$ nov., Sphingomonas sanguis sp. nov. and Sphingomonas terrae sp. nov. Syst. Appl. Microbiol. 16:227-238.

25. Takeuchi, M., and A. Yokota. 1994. Phylogenetic analysis of Kineococcus aurantiacus based on 16S rRNA gene sequences. FEMS Microbiol. Lett. 116: 7-12.

26. Uchida, K., and K. Aida. 1977. Acyl type of bacterial cell wall: its simple identification by colorimetric method. J. Gen. Appl. Microbiol. 23:249-260

27. Wako Pure Chemical Industries, Ltd. 1989. Technical note on the system of PTC-amino acid analysis. Wako Pure Chemical Industries, Ltd., Osaka, Japan. (In Japanese.)

28. Yamada, K., and K. Komagata. 1972. Taxonomic studies on coryneform bacteria. IV. Morphological, cultural, biochemical, and physiological characteristics. J. Gen. Appl. Microbiol. 198:399-416.

29. Yokota, A., M. Takeuchi, T. Sakane, and N. Weiss. 1993. Proposal of six new species in the genus Aureobacterium and transfer of Flavobacterium esteraromaticum Omelianski to the genus Aureobacterium as Aureobacterium esteraromaticum comb. nov. Int. J. Syst. Bacteriol. 43:555-564.
30. Yokota, A., M. Takeuchi, and N. Weiss. 1993. Proposal of two new species in the genus Microbacterium: Microbacterium dextranolyticum sp. nov, and Microbacterium aurum sp. nov. Int. J. Syst. Bacteriol. 43:549-554.

31. Yokota, A., T. Tamura, T. Nishii, and T. Hasegawa. 1992. Kineococcus aurantiacus gen. nov., sp. nov., a new aerobic gram-positive, motile coccus with meso-diaminopimelic acid and arabinogalactan in the cell wall. Int. J. Syst. Bacteriol. 43:52-57.

32. Zgurskaya, H. I., L. I. Evtushenko, V. N. Akimov, and L. V. Kalakoutskii. 1993. Rathayibacter gen. nov., including the species Rathayibacter rathayi comb. nov., Rathayibacter tritici comb. nov., Rathayibacter iranicus comb. nov., and six strains from annual grasses. Int. J. Syst. Bacteriol. 43:143-149.

33. Zgurskaya, H. I., J. I. Evtushenko, V. N. Akimov, H. V. Voyevoda, T. G. Dobrovolskaya, L. V. Lysak, and L. V. Kalakoutskii. 1992. Emended description of the genus Agromyces and description of Agromyces cerinus subsp. cerinus sp. nov., subsp. nov., Agromyces cerinus subsp. nitratus sp. nov., subsp. nov., Agromyces fucosus subsp. fucosus sp. nov., subsp. nov., and Agromyces fucosus subsp. hippuratus sp. nov., subsp. nov. Int. J. Syst. Bacteriol. 42:635641 